\title{
The Impact of Parents Education, Parents Income, Teacher Education and Locality of School on Students Relinquish School During Primary Level in DG Khan District
}

\author{
Sunila Ahsan ${ }^{1}$, Nadeem Iqbal ${ }^{2}$, Nosheen Farooq ${ }^{3}$ \\ ${ }^{1}$ Student M.Phil( Education) Indus International Institute D.G.Khan \\ ${ }^{2}$ Faculty of Management Sciences Ghazi University DG Khan \\ ${ }^{3}$ Faculty of Social Sciences, Indus International Institute DG Khan \\ E-mail address: drnadeemiqbal1@gmail.com
}

\begin{abstract}
Keyword: Parents Education; Parents Income; Teacher Education; Locality of School; Students Relinquish; Multiple Regression; Primary Level of Education
\end{abstract}

\begin{abstract}
In this study, reasearcher examined the impact of parent's education, parents income, teacher education and locality of school on students relinquish school during primary level .The study data was collected from different urban and rural areas of D.G.Khan schools. The study used the multiple regressions to analyze the effect of parent's education, parent'sincome, teacher education and locality of school on students relinquished school during primary level of education. This research findings show that parent's education, parents income and teacher education were significant and locality of school was insignificant. It is concluded that parent's education, parents income, teacher education are affected to students relinquished school during primary level in the districtand locality of school has no affect on students relinquish school during primary.
\end{abstract}

\section{INTRODUCTION}

It is generally accepted that education is the backbone of the any society for growth and development. So it is considered that every child has the right to get education and become fruitful element of the society. So everyone has right to achieve it everytime. It is observed that every society is developed through education. Education is the main pillar of any society (Adams,1998). Primary education is the initial level of all educational systems.It is responsibility of the state that every child should be able to complete the course of primary education. Primary education is the first step of compulsory education. Primary education is the most basic formal education and is value very highly for preparing teamers for secondary education, World of work ,scientific and technical knowledge. Basic education enhances the human capital development which is basic element of income generating activity. It is observed that education is negatively correlated with poverty. Parents education provide a "better" environment for their children to continuous education. If the influence of parents' level of education and parents income on student than outcomes might be best (Joan M. T. Smrekar C W ,2009).Higher level of parents literacy and income developed in their child social or problem solved skills and he reached successfuly in a school. The low parents income directly nagative impact on students educational achievements.Parents education and parents income have main position in child educational life but researcher dose not ignored the importance of teacher education \& locality of school. School poverty is distribe the students education. Students in urban areas have better academic outcomes than rural areas but researcher saw the relinquishment continued in urban $\&$ rural areas. Teachers education and school quality have very strong impact on academic achievement or continuity among pupils . Researcher identified necessarily teachers education have the power to influenced of student education. School structure variables such as school location and school sector are significantly link to students. Child mentally better grow in better environment.Parent's education provides a betterenvironment for their children to complete education to earn smooth money. Thus, 
the influence of socio-economic status and parents' level of education on student outcomes might be best for the economic stability and poverty reduction as well.

This study wants to measure the impact of parent's education, parent'sincome; teacher education and locality of school on students relinquish school during primary level. The purpose of this study was to examine the possible impact of parents education, parents income,teacher education and locality of school on students relinquished school during primary level of education. The main purposed of this study was to find out the reason of students relinquish schools during primary level so that the reason may be minimize and student may be kept for education in the class. For this purposed,data was collected from different schools of local area of D.G.Khan District.The samples size of study was71 students as they were relinquished schools during primary level.The hypothesis of this research was parents education, parents income,teacher education and locality of school had impact on students relinquished school during primary level of education quo hypothesis was parents education, parents income,teacher education and locality of school had no impact on students relinquished school during primary level of education.

The current study seeks to answer the following questions:

(A) What effect of parents' education on students relinquished school during primary level?

(B) What effect of parent's income on students relinquished school during primary level?

(C) What impact of teacher education on students relinquished school during primary level?

(D) What impact of locality of school on students relinquished school during primary level?

\section{LITERATURE REVIEW}

In this literature review part, it was tried to analyze the effect of parents' back-ground(parents' education,parents' income), teacher education, and locality of school on students relinquished school during primary level.Young (1998) Claimed that, students of urban and rural areas of schools were different in their characteristies. OECD (2009) submitted a report and analysed the importance of a school's location. In research they controlled the parents socioeconomic characteristics and analyed the results from reading test. The results show that $8 \%$ difference in Colombia, minimum and maximum populated Zones differed by around 4\%. Grissmer et al, (1994)found a positive relationship between children's and parents level of education and parents income.Saracho (2000) suggested that parents level of education played very important role in students educational development. Ersado (2005), analysised the cause of students continue their education and case was parents level of education. Murray (2002)noticed that every economicaly successful parents have successful children in education. Teacher education is very important Variable in a student life.A trained and qualified teacher can make education breeze and engrossing for their students. Greenberg et al(2004) suggested that researchers and policymakers should have improving teacher quality.Rivkin and Kain (2005) identified teachers and teaching quality increased the education quality.Mike (2008) evaluated and examined how socioecomic factors affected primary school dropout in Uganda. For that research,researcher used National Service Delivery Survey data(2004). The result of research was parental education ,household size and number of economically active members were played significance role in school dropout in primary education.Economicaly low Schools faced many problems such as unemployment, migration of the qualified teachers, and these schools gain low educational achievements (Sammons,2009). Zhang,\& Rozelle (2012) concluded that poverty was main and primary cause for school drop in primary education. Kainuwa \& Yusuf (2013)examined the relation of Household income and drop out ,finding of this research was household income linked to chilren education and drop out of school. The most recent report of education department (jan 2014), was only 2\%students continued their education and reached in high schools cause of low family income . Pedro Carneiro and Heckman (2003) used Stephen Cameron (1998) US data and Arnaud Chevalier and Gauthier Lanot (2002) UK National Child Development Study data and found the result.The result show that in chilldren education parents education was significant and parents income was insignificant. Alisa (2010)found the difference from poor and rich students during primary level and its diffrence 
increased day by day. Although children education linked with parent's education and parents income but researchers force the home literacy environment that was important characteristic.

\section{METHODOLOGY}

This study collected secondary data from different urban and rural areas of D.G.Khan schools. The data consisted of 71 students. The independent variables in this study were Parents Education,Parents Income,Teacher Education and Locality of schools. In multiple regression, parents education was divided in two categroies educated or uneducated. Same as locality was divided rural or urban areas,but teacher education was divided in three categroies F.A/C.T, B.A/B.ed and M.A. The dependent variable was stay duration of students during primary level and variable was showing through month of study duration. The data was analysised through statistic techniqe Multiple Regression. The multiple regression model was:

$\mathrm{Y}=\mathrm{a}+\mathrm{b}_{1} \mathrm{X}_{1}+\mathrm{b}_{2} \mathrm{X}_{2}+\mathrm{b}_{3} \mathrm{X}_{3}+\mathrm{b}_{4} \mathrm{X}_{4}$

$\mathbf{Y}$ was the value of students study duration

a (Alpha) was the Constant or intercept

$b_{1}, b_{2}, b_{3}, b_{4}$ were the Slope (Beta coefficient) for $X_{1}, X_{2}, X_{3}, X_{4}$

$\mathbf{X}_{\mathbf{1}}$ First independent variable that was parents education

$\mathbf{X}_{\mathbf{2}}$ Second independent variable that was parents income

$\mathrm{X}_{3}$ Third independent variable that was teacher education

$\mathrm{X}_{4}$ Fourth independent variable that was school locality.

\section{RESULTS}

In current study,used the Multiple Regression and type of Enter method. According to table 1, $\mathrm{R}$ value is .857 and $\mathrm{R}$ Squar value is .734 . In persontage $\mathrm{R}$ Squar value is $73 \%$. This value show model $73 \%$ fit and only $27 \%$ error .

\section{Table 1}

\begin{tabular}{|c|c|c|c|c|c|c|c|c|c|}
\hline \multirow[b]{3}{*}{ Model } & \multirow[b]{3}{*}{$\mathrm{R}$} & \multicolumn{8}{|c|}{ Model Summary } \\
\hline & & & & Std Frror of the & \multicolumn{5}{|c|}{ Change Statistics } \\
\hline & & R Square & Adjusted R Square & Estimate & R Square Change & F Change & df1 & df2 & Sig. F Change \\
\hline 1 & $.857^{\mathrm{a}}$ & .734 & .718 & 10.445 & .734 & 45.623 & 4 & 66 & .000 \\
\hline
\end{tabular}

a. Predictors: (Constant), School.location, Parents.Edu, Teacher.Edu, Parents.income

Table 2 show that in parents education $\mathrm{B}$ value is 9.480 this valueis grater than std.error 3.127 and significant value 0.003 is less than $\alpha=0.05$.This is show parents education significant value.In parents incone $B$ value is 0.076 this value is large std.error 0.014 and significant value .000 is much smaller than $\alpha=0.05$,It is a significant value. In taecher education B 10.653 this value is bigger than std.error 3.069 and significant value 0.001 is smaller than $\alpha=0.05$,It is a significant value.If all three varibles are significant than results show parents education, parents income and teacher educationare affecting students relinquish school during primary level.But school locality significant value 0.088 is grater than $\alpha=0.05$.In other words, school locality is insignificant and its no impact on students relinquish school during primary level. 
Table 2

\begin{tabular}{|c|c|c|c|c|c|c|}
\hline & \multirow[b]{2}{*}{ Model } & \multicolumn{2}{|c|}{ Unstandardized Coefficients } & \multirow{2}{*}{$\begin{array}{c}\text { Standardized } \\
\text { Coefficients }\end{array}$} & \multirow[b]{2}{*}{$\mathrm{T}$} & \multirow[b]{2}{*}{ Sig. } \\
\hline & & $\mathrm{B}$ & Std. Error & & & \\
\hline \multirow[t]{5}{*}{1} & (Constant) & -4.613 & 4.640 & & -.994 & .324 \\
\hline & Parents.Edu & 9.480 & 3.127 & .243 & 3.031 & .003 \\
\hline & Parents.income & .076 & .014 & .444 & 5.448 & .000 \\
\hline & Teacher.Edu & 10.653 & 3.069 & .268 & 3.471 & .001 \\
\hline & School.location & 5.304 & 3.062 & .136 & 1.732 & .088 \\
\hline
\end{tabular}

a. Dependent Variable: Stay.duration

\section{DISCUSSION}

The main objective of this discussion is to identify the problem and improve the quality of students learning.The variables considered in this study are Parets Education ,Parent Income , Teacher Education ,Locailty of School.For parents education the data has provided many evidence against the quo hypothesis. This it similar with other researches that parents education is linked with students education ( Grissmer et al,1994, Saracho 2000, Ersado 2005, Mike 2008 Kainuwa \& Yusuf 2013). In short,Recent discussions about parents education data presentationin this study indicate that low parents education is associated with perception of higher level drop out of school during primary level of education. According to parents income ,the data rejected the quo hypothesis.The findings reveal a relationship between parents income and childrens education and its finding is consistent with previous research (Murray 2002, , Pedro Carneiro and Heckman 2003, Mike 2008, Zhang \& Rozelle 2012, Kainuwa \& Yusuf 2013). In this research,those who childrens thats parents are economicaly weaker relnquishe school during primary level and economicaly strong students continiue their education. The contribution of teachers education is positive in students education and again rejected the quo hypothesis. This research is consistent with previous research(Greenberg,Rhodes,Ye\&Stancavage 2004 Rivkin, Hanushek and Kain 2005, Sammons,2009). The teachers education factor is an important in continuing students education. In locailty of school,the data accepted the quo hypothesis. This finding is incosistent with previous research (Hannaway\&talbert 1993and young 19s98, Sammons,2009 ).Its mean school locality is not important and in education school locality has no impact on students relinquishe school during primary level of education.

\section{CONCLUSIONS}

One of the biggest problems in today our country is low literacy level. The results show parents educational, parents income and teacher education have a significant effect on their childrens continuty education. The high educated parents force their own child's to continue education. Similarly teacher education and skill of teacher play a very important role that students not relinquished school during primary level. Parents will be invest income in their children's education by means of providing educational requirements will better. According to resulte,locality of school is not important in children's education.If we improve all of variables than researcher see a bright future of our childrens and country. 


\section{References}

[1] Carneiro, P., Hansen, K. T., \& Heckman, J. J. (2003). Estimating Distributions of Treatment Effects with an Application to the Returns to Schooling and Measurement of the Effects of Uncertainty on College (No. w9546). National Bureau of Economic Research.

[2] Darling-Hammond, L., \& Youngs, P. (2002). Defining" highly qualified teachers": What does" scientifically-based research" actually tell us?. Educational researcher, 13-25.

[3] Goodman, A., \& Gregg, P. (Eds.). (2010). Poorer children's educational attainment: how important are attitudes and behaviour? (p. 6). York: Joseph Rowntree Foundation.

[4] Kainuwa, A., \& Yusuf, N. B. M. (2013). Influence of Socio-Economic and Educational Background of Parents on their Children's Education in Nigeria.International Journal of Scientific and Research Publications, 3(10), 1-7.

[5] Knighton, T., Brochu, P., \& Gluszynski, T. (2010). Measuring up: Canadian results of the OECD PISA study: the performance of Canada's youth in reading, mathematics and science 2009: first results for Canadians aged 15.

[6] Levin, H. M. (1997). Raising school productivity: An x-efficiency approach.Economics of Education Review, 16(3), 303-311.

[7] Okumu, I. M., Nakajjo, A., \& Isoke, D. (2008). Socioeconomic determinants of primary school dropout: the logistic model analysis.

[8] Rivkin, S. G., Hanushek, E. A., \& Kain, J. F. (2005). Teachers, schools, and academic achievement. Econometrica, 73(2), 417-458.

[9] Sammons, P. (2009). The dynamics of educational effectiveness: a contribution to policy, practice and theory in contemporary schools.

[10] Saracho, O. N. (2000). Literacy development in the family context. Early Child Development and Care, 163(1), 107-114.

[11] Visit APA's CYouth and Families ofice website: http:// www. Apa . org / Pi / families / rch retrieves on 2 august 20.

[12] Yi, H., Zhang, L., Luo, R., Shi, Y., Mo, D., Chen, X., ... \& Rozelle, S. (2012). Dropping out: Why are students leaving junior high in China's poor rural areas?.International Journal of Educational Development, 32(4), 555-563. 